\title{
Differential Nitrogen Response of Annual and Perennial Grasses
}

\author{
W. E. MARTIN, CECIL PIERCE, AND V. P. OSTERLI \\ Extension Soils Specialist, Modoc County Farm Advisor \\ formerly in San Luis Obispo County, Extension Range \\ Improvement Specialist, respectively, Agricultural Ex- \\ tension Service, University of California.
}

It has often been observed on winter range in California that annual grasses appear to respond more to nitrogen fertilizer than do perennial grasses when grown together. In a Lake County grazing test with sheep (Martin and Berry 1958), an annual grass plus Hardinggrass mixture produced little more meat when fertilized with nitrogen than did a straight annual grass pasture similarly fertilized. It was felt that the bulk of the stimulation which about doubled days of grazing and meat production came from increased growth of annual grasses.

Similarly at the Massey Experimental Range in San Diego County (Kay, Walker, Street and Myler 1958) hand separations of April clippings of fertilized and unfertilized areas showed very great response from nitrogenphosphorus fertilizers in the annual grass fraction with only slight and not statistically significant increases in the perennial grasses.

In 1961 a field observation was made at the Eagle Ranch in San Luis Obispo County that may be of interest. In fertilizing a hay field composed of Hardinggrass (Phalaris tuberosa, var. stenoptera) and annual grass a single strip of about 600 pounds of ammonium sulfate was applied around the field. Next to it was an unfertilized strip, while the balance of the field was fertilized with approximately 300 pounds of ammonium sulfate per acre. It appeared that most of the response in the lightly fertilized section of the field was by the annual grasses while in the high nitrogen strip Hardinggrass was greatly stimulated. Quadrats were cut at three positions in each strip and separations made into annual and perennial grasses. The samples were then dried and yields of each fraction calculated. The results are shown in Table 1. Reported yields are averages from three quadrats in each strip.

The "Low" nitrogen stimulated principally the annual grasses which were mostly Soft Chess, (Bromus mollis), while major increase in growth of Hardinggrass took place only where "High" nitrogen was applied.

\section{Experimental Methods}

Recognizing that the observations in the strip treatments might have been border effects or due to an old hay strip around the field, a replicated nitrogen rate test was set up nearby in the fall of 1961, prior to the 196162 winter growing season. Ammonium sulfate was applied at rates to provide $0,60,120$ and 240 pounds of nitrogen per acre in strips $10 \times 80$ feet each with four replications. Harvest was

Table 1. Response of Annual and Hardinggrass to Nitrogen Fertilization, 1961. Eagle Ranch-Farmer Treatments

\begin{tabular}{|c|c|c|c|}
\hline \multirow[b]{2}{*}{ Strip Treatment } & \multicolumn{3}{|c|}{ Observed Yield (Dry Weight Lbs/A) } \\
\hline & Total & Annual Grass & Hardinggrass \\
\hline "High N" approx. 120 N/A & 5779 & 2427 & 3352 \\
\hline None & 1718 & 938 & 780 \\
\hline "Low N" approx. $60 \mathrm{~N} / \mathrm{A}$ & 3984 & 2496 & 1488 \\
\hline "L.S.D." & $\overline{1495}$ & 1127 & 1253 \\
\hline
\end{tabular}


Table 2. Effect of Nitrogen Fertilization on Yield and Botanical Composition of Hardinggrass and Annual Grass Mixture. Fertilized November 28, 1961-Harvested May 8, 1962

\begin{tabular}{|c|c|c|c|c|c|c|}
\hline \multirow[b]{2}{*}{$\begin{array}{l}\text { Nitrogen } \\
\text { Applied }\end{array}$} & \multirow{2}{*}{$\begin{array}{c}\text { Yield of } \\
\text { Fresh } \\
\text { Weight }\end{array}$} & \multirow{2}{*}{$\begin{array}{c}\% \\
\text { Dry } \\
\text { Matter }\end{array}$} & \multicolumn{3}{|c|}{ Yield of Dry Material } & \multirow{2}{*}{$\begin{array}{c}\% \\
\text { Harding- } \\
\text { grass }\end{array}$} \\
\hline & & & $\begin{array}{c}\text { Total } \\
\text { Forage }\end{array}$ & $\begin{array}{l}\text { Harding- } \\
\text { grass }\end{array}$ & $\begin{array}{c}\text { Annual } \\
\text { Grass }\end{array}$ & \\
\hline- - Lbs./A & A. -- & & --- & Lbs./A. & --1 & \\
\hline None & 7242 & 25.6 & 1856 & 1231 & 625 & 66.3 \\
\hline 60 & 9033 & 27.2 & 2454 & 1259 & 1195 & 51.3 \\
\hline 120 & 10452 & 26.5 & 2775 & 1433 & 1342 & 51.6 \\
\hline 240 & 14407 & 24.6 & 3549 & 2060 & 1489 & 58.0 \\
\hline L.S. D. $5 \%$ & $\overline{1508}$ & 1.7 & 528 & $\overline{4} \overline{2}$ & $\overline{4} \overline{25}$ & … \\
\hline
\end{tabular}

Table 3. Effect of Nitrogen Fertilization on Composition and Nitrogen Reof Hardinggrass and Annual Grass Mixture. Fertilized November 28, 1961-Harvested May 8, 1962.

\begin{tabular}{|c|c|c|c|c|c|c|c|}
\hline \multirow{2}{*}{$\begin{array}{l}\text { Nitrogen } \\
\text { Applied } \\
\text { Lbs/A }\end{array}$} & \multicolumn{3}{|c|}{ Nitrogen in } & \multicolumn{3}{|c|}{ N Harvested in Crop of } & \multirow{2}{*}{$\begin{array}{c}\text { Recovery } \\
\text { of } \mathrm{N} \\
\text { Applied }\end{array}$} \\
\hline & $\begin{array}{l}\text { Harding- } \\
\text { grass }\end{array}$ & $\begin{array}{c}\text { Annual } \\
\text { Grass }\end{array}$ & $\begin{array}{l}\text { Whole } \\
\text { Forage }\end{array}$ & $\begin{array}{l}\text { Harding- } \\
\text { grass }\end{array}$ & $\begin{array}{c}\text { Annual } \\
\text { Grass }\end{array}$ & $\begin{array}{l}\text { Whole } \\
\text { Forage }\end{array}$ & \\
\hline & --1 & (Percent) & -- & --- & (Pounds) & --- & (Percent) \\
\hline 0 & 1.85 & 1.44 & 1.70 & $22.6^{1}$ & $8.8^{1}$ & 31.41 & $\cdots$ \\
\hline 60 & 1.96 & 1.39 & 1.68 & $1.8^{2}$ & $7.7^{2}$ & $9.5^{2}$ & 31.6 \\
\hline 120 & 2.06 & 1.42 & 1.75 & $7.0^{2}$ & $10.3^{2}$ & $15.3^{2}$ & 12.7 \\
\hline 240 & 2.49 & 1.73 & 2.17 & $28.9^{2}$ & $16.7^{2}$ & $45.6^{2}$ & 19.0 \\
\hline $\begin{array}{l}\text { L.S. D. } \\
1 \mathrm{~N} / \mathrm{A} \text { he } \\
2 \mathrm{Gain}\end{array}$ & .16 &.$\overline{16}$ & .09 & 8.3 & 14.7 & $\overline{10.7}$ & 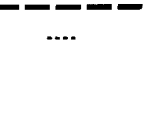 \\
\hline
\end{tabular}

inggrass was still green at harvest while the annual grasses were quite mature and contained less moisture.

(b) The nitrogen content of the forage was increased only in the highest nitrogen treatments. These data shown in Table 3 indicate that the total nitrogen of the Hardinggrass increased slightly with lower rates of nitrogen, but strikingly when 240 pounds of nitrogen were applied. somewhat lower percent nitrogen than did Hardinggrass. The nitrogen content of the annual grass fraction was increased by nitrogen applications only at the highest level after yield responses had ceased.

Percent nitrogen of whole forage was increased only at the highest nitrogen application.

(c) Nitrogen recovery by the two types of grass showed that the annual grasses get more of the nitrogen harvested at low nitrogen levels, while the Hardinggrass took up most of the fertilizer nitrogen at high levels of fertilization. Total recovery of fertilizer nitrogen in the harvested crop was 30 percent of that applied at the low rate but only 13 percent to 19 percent at the higher nitrogen levels of fertilization.

\section{Summary}

It has been observed that Hardinggrass, a perennial, behaves quite differently than does Soft Chess, an annual brome grass, when both are fertilized with nitrogen in a mixed stand.

At low rates of nitrogen the annual grasses appear to get more of the nitrogen and respond greatly with little effect on the perennial Hardinggrass.

As nitrogen rates are further increased little additional growth of annual grasses is observed while Hardinggrass is stimulated and picks up more of the added nitrogen.

\section{LITERATURE CITED} AND MYLER, J. L. 1958. Range Management Investigations-Demon stration Ranges. Univ. of Calif. Range Mangt. Investigations. Progress Report Mimeo. pp. 30.

Martin, W. E. AND L. J. BerRy. 1958. Range Fertilization in a Dry Year. Univ. of Calif. Agric. Ext. Serv. Mimeo. pp. 20.

SNEDECOR, G. W. 1946. Statistical Press.
Kay, B. L., WALKer, C. F., STreet, J., Methods. Iowa State College

The new and as yet uncharted lines of human endeavor, fulfillment, and adventure open to the rural community and agriculture are bound to find men and women willing to chance it as our sodbusting ancestors did a generation ago.-The Yearbook of Agriculture 1963. 